\title{
Краткие сообшения
}

УАK 613.6:669.168

КуАряшов И.Н.

\section{ГРУППОВОЙ И ИНАИВИАУААЬНЫЙ ПРОФЕССИОНААЬНЫЙ РИСК УТРАТЫ ЗАОРОВЬЯ РАБОЧИХ ФЕРРОСПААВНОГО ПРОИЗВОАСТВА}

\begin{abstract}
ФБУН «Екатеринбургский медицинский научный центр профилактики и охраны зАоровья рабочих промпреАприятий»
\end{abstract} Роспотребнадзора, ум. Попова, 30, Екатеринбург, РФ, 620014

\begin{abstract}
Проведена оценка группового и индивидуального профессионального риска утраты здоровья работников ферроспиавного производства. Выявлено, что в основных профессиях плавильного цеха ферроспиавного завода формируется среАний групповой профессиональный риск и высокий индивидуальный риск.

КАючевые слова: групповой и индивидуальный профессиональныгй риск; ферросплавное производство
\end{abstract}

Kudryashov I.N. Group and individual occupational risk of health loss in workers engaged into ferroalloy industry. Yekaterinburg Medical Research Center for Prophylaxis and Health Protection of Industrial Workers, 30, Popova str., Yekaterinburg, Russian Federation, 620014

The authors assessed group and individual occupational risk of health loss in workers of ferroalloy industry. Findings are that main occupations of melting workshop are connected with formation of average group occupational risk and high individual risk.

Key words: group and individual occupational risk; ferroalloy industry

В настоящее время в мире насчитывается около сотни преАприятий, занимающихся производством ферросплавов, из них более половины располагается на территории России. На протяжении послеАних мет проводятся работы по оценке профессионального риска работников одного из ферросплавных заводов СверАловской области, занимающего второе место по объему производства ферроспиавов на территории РФ. Основная продукция преАприятия феррохром (высоко-, среАне- и низкоугмеродистый), а также кремнистые ферросплавы (ферросилиций, ферросикикохром).

Ранее была проведена оценка профессионального риска рабочих основных профессий в плавильном цехе по методике Р 2.2.1766-03, результаты которой показали, что в профессии «плавильщик ферросплавов» существует высокий риск развития пылевой патологии, а в профессиях «горновой ферросплавной печи» и «машинист крана метаммургического произвоАства - среАний профессионамьный риск $[1,3]$.

При анализе материалов аттестации рабочих мест и сопоставления их с провеАенными контрольными замерами обнаружено, что фактические концентрации (уровни) вредных факторов не соответствоваки контрольным замерам (послеАние были выше). Этим объяснялось несоответствие межАу результатами оценки профессионального риска развития пылевой патологии по гигиеническим и меАико-биологическим кри- териям, что потребовало проведения дополнительных исслеАований на Аанном произвоАстве. В частности, Аополнительно была проведена оценка индивидуацьного профессионацьного риска работников основных профессий плавильного цеха с помощью специальной методики [2], которая позволяет дополнить Аанные аттестации рабочих мест показатемями текущего уровня зАоровья, возраста и стажа работников, а также сравнить и ранжировать работников по уровню профессионацьного риска [4].

Цемь исслеАования - провести оценку группового и инАивиАуального профессионацьного риска утраты зАоровья рабочих основных профессий плавильного цеха ферроспиавного производства.

Материамы и методика исследования. Работы проводились в плавильном цехе, выпускающем низкоуглеродистый и среАнеуглеродистый феррохром (Ао 65\%).

Амя оценки профессионального риска рабочих основных профессий были использованы Аве методики:

- методика оценки группового профессионального риска, основанная на материацах аттестации рабочих мест и профессиональной заболеваемости за Аесятикетний периоА;

- методика оценки инАивиАуамьного профессионального риска, включающая не только оценку условий труаа и учет абсолютного числа профессиональных заболеваний на производстве, но и исходный 
уровень состояния зАоровья работника, его возраст, стаж работы во вредных условиях труАа, а также степень защищенности среАствами индивидуальной защиты (СИЗ) и вероятность травмирования на рабочем месте.

Проанализированы результаты аттестации рабочих мест, а также данные о численности работающих выбранных профессий, их возрасте, стаже в профессии, состоянии зАоровья (группа Аиспансеризации) и количестве несчастных скучаев на производстве за текущий гоА.

Состояние здоровья работников (группа Аиспансеризации) определялось на основании данных о текущей заболеваемости за посмеАний гоА, регистрируемой в медсанчасти завоАа, включающей в себя число случаев острых респираторных вирусных инфекций (ОРВИ) и число Аней нетрУАоспособности за гоА, а также наличие хронических неинфекционных заболеваний у работника.

В группу исследования вошли 156 работников основных профессий плавильного цеха ферроспиавного производства, а именно: 46 плавильщиков ферросплавов, 54 горновых ферроспиавных печей и 56 машинистов кранов.

Результаты исследований и их обсуждение. Технология выплавки рафинированного феррохрома осуществляется силикотермическим способом в наклоняющихся электропечах мощностью 7,0 MBA с использованием в качестве основного сырья порошковых и хромистых руА, в качестве восстановителя хрома ферросиликохром и в качестве флюса - известь.

Основными профессиями в плавильном цехе явмяются плавильщик ферросплавов, горновой ферросплавной печи и машинист крана. Плавимьщик ведет и корректирует процесс выплавки сплава, загружает шихту с помощью завалочных машин, задает добавки вручную или через механизированную систему шихтоподачи, также оказывает при необходимости помощь горновому во время выпуска расплава. В обязанности горнового входит обслуживание горна ферроспиавной печи, выполнение работ по подготовке ковшей к выпуску. Он же обеспечивает подготовку изможниц к размиву металма из ковшей, производит выпуск метамла из печи. Машинист крана осуществмяет перемещение ковшей с металмом в пределах участка.

Результаты работы показали, что основными факторами профессионального риска на рабочих местах являлись аэрозоли преимущественно фиброгенного действия, произвоАственный шум, нагревающий микроклимат, недостаточная освещенность. На основании гигиенических критериев в профессиях плавильщика ферросплавов и горнового ферросплавной печи групповой профессиональный риск, рассчитанный по общепринятой методике Р 2.2.1766-03, опредемен как среАний (категория 1Б), а в профессии машиниста крана - малый (категория 1Б). Согласно результатам гигиенических исследований, можно ожидать развития у работников скучаев профессиональных заболеваний органов Аыхания и нейросенсорной тугоухости.

В настоящее время на производстве регистрируются случаи профессиональной патологии органов Аыхания. На основании медико-биологических критериев на преАприятии в Аанных профессиях существует среАний групповой профессиональный риск (категория 1A).

В ходе анализа персонифицированной информации о состоянии зАоровья работников были получены параметры, Аающие преАставление о рабочих изучаемых профессий. Аанные о возрасте и стаже работников преАставлены в табл. 1.

Таблица 1

Распределение работников основных профессий по возрасту и стажу

\begin{tabular}{|c|c|c|c|c|c|c|c|c|c|c|}
\hline \multicolumn{3}{|l|}{ Профессия } & \multicolumn{4}{|c|}{ Возраст, мет } & \multicolumn{4}{|c|}{ Стаж, иет } \\
\hline & & & $20-29$ & 30-39 & $40-49$ & 50 и более & $1-5$ & $6-10$ & 11-20 & 21 и более \\
\hline \multirow{2}{*}{ Пиавильщик ферроспиавов } & aбc. & 46 & 7 & 22 & 6 & 11 & нет & 21 & 18 & 7 \\
\hline & $\%$ & 100 & 15,2 & 47,8 & 13,1 & 23,9 & нет & 45,7 & 39,1 & 15,2 \\
\hline \multirow{2}{*}{ Горновой ферросплавной печи } & $\mathrm{a} 6 \mathrm{c}$. & 54 & 24 & 28 & 2 & нет & 45 & 9 & нет & нет \\
\hline & $\%$ & 100 & 44,4 & 51,9 & 3,7 & нет & 83,3 & 16,7 & нет & нет \\
\hline \multirow{2}{*}{ Машинист крана } & $\mathrm{a} 6 \mathrm{c}$. & 56 & 18 & 14 & 12 & 12 & 21 & 16 & 9 & 10 \\
\hline & $\%$ & 100 & 32,2 & 25,0 & 21,4 & 21,4 & 37,5 & 28,6 & 16,1 & 17,8 \\
\hline
\end{tabular}

Таблица 2

УАемьный вес работников, отнесенных к группам инАивиАуамьного профессионахьного риска, \%

\begin{tabular}{|c|c|c|c|c|c|c|}
\hline \multirow{2}{*}{$\begin{array}{c}\text { Инаивидуальный } \\
\text { профессионацьный } \\
\text { риск }\end{array}$} & \multicolumn{2}{|c|}{$\begin{array}{c}\text { Пмавимьщик ферроспмавов } \\
(\mathrm{n}=46)\end{array}$} & \multicolumn{2}{|c|}{$\begin{array}{c}\text { Горновой ферроспмав- } \\
\text { ной печи }(\mathrm{n}=54) \\
\end{array}$} & \multicolumn{2}{|c|}{$\begin{array}{c}\text { Машинист метаммургического } \\
\text { крана }(\mathrm{n}=56) \\
\end{array}$} \\
\hline & $\begin{array}{c}\text { вся } \\
\text { группа }\end{array}$ & $\begin{array}{c}\text { со стажем } \\
>10 \text { мет, }(n=25) \\
\end{array}$ & $\begin{array}{c}\text { вся } \\
\text { группа } \\
\end{array}$ & $\begin{array}{c}\text { со стажем } \\
>10 \text { пет, }(n=0) \\
\end{array}$ & $\begin{array}{c}\text { вся } \\
\text { группа }\end{array}$ & $\begin{array}{c}\text { со стажем } \\
>10 \text { мет, }(n=19)\end{array}$ \\
\hline Высокий & 41,3 & 60,0 & 13,0 & нет & 35,7 & 89,5 \\
\hline СреАний & 43,5 & 40,0 & 57,4 & нет & 42,9 & 10,5 \\
\hline Низкий & 15,2 & нет & 29,6 & нет & 21,4 & нет \\
\hline
\end{tabular}


Основное количество работников составцяют Аица в возрасте Ао 40 мет (более 50\% работников). Стоит отметить, что в профессиях плавильщика ферросплавов и машиниста крана более $20 \%$ работников имеют возраст от 50 мет и старшее.

В профессиях плавильщика ферросплавов и машиниста крана трудятся более стажированные работники (трудовой стаж свыше 10 мет - у 54,3\% и $33,9 \%$ работников соответственно), чем в профессии горнового ферросплавной печи (стаж работы до 5 мет - у $83,3 \%$ работников).

Оценка индивидуального профессионального риска показала, что у работников основных профессий наблюАается высокий, среАний и низкий профессиональный риск нарушения зАоровья в процессе труда (табл. 2)

Распредемение работников по группам риска зависело от возраста, стажа и состояния зАоровья. Так, у работников при стаже более 10 мет в профессиях плавильщик ферросплавов и машинист крана наблюАался высокий профессиональный риск от 60 Ао $89,5 \%$ соответственно.

Следует отметить, что среди стажированных работников рассмотренных профессий (при стаже более 10 мет) отсутствует низкий профессиональный риск.

Кроме этого, в профессии горновой ферросплавной печи отсутствовали стажированные работники, а распределение профессионального риска в группе зависело, в основном, от текущего состояния зАоровья рабочих.

\section{Выводы:}

1. Групповой профессиональньй риск у работников основных профессий ферросплавного производства определяется как средний риск нарушения здоровья в прочессе труда. При оченке индивидуального профессионального риска, учитывающего не только условия труда и профессиональную заболеваемость, но и другие критерии (возраст, стаж и состояние здоровья) выяяяено, что работающие подвергаются высокому профессиональному риску.

2. Применение методики индивидуального профессионального риска позволяет разработать конкретные адресные мероприятия по управлению профессиональными рисками для каждого работника производства.

\section{СПИСОК АИТЕРАТУРЫ}

1. Кудрямов И.Н. // ЗАоровье населения и среАа обитания, 2012. — №9. - C. 4-5.

2. Методика расчета индивидуального профессионального риска в зависимости от условий труАа и состояния зАоровья работника: Методические рекомендации. Утв. Председателем Научного совета 45 МинзАравсоцразвития России и РАМН «МеАико-экомогические проблемы зАоровья работающих» 23.06.2011 г. - M.

3. Руководство по оценке профессионального риска амя зАоровья работников. Организационно-методические основы, принципы и критерии оценки: Р 2.2.1766-03. - М., 2004.

4. Симонова Н.И. // МеА. труАа и пром. экол. - 2012. №1. - С. 13-19.

\section{REFERENCES}

1. Kudryashov I.N. // Zdorov'e naseleniya i sreda obitaniya. 2012. - 9. - P. 4-5 (in Russian).

2. Method to calculate individual occupational risk in dependence on work conditions and workers' health state: Methodic recommendations. Approved by 45 Scientific Council Chairman with RF Health and Social Development Ministry and RAMSc «Medical and ecologic problems of workers' health» on 23.06.2011. - Moscow (in Russian).

3. Manual on evaluating occupational risk for workers' health. Organizational and methodic basics, principles and criteria of evaluation. R 2.2.1766-03. - Moscow, 2004 (in Russian).

4. Simonova N.I. // Industr. med. - 2012. - 1. - P. 13-19 (in Russian).

Поступияа 22.11.2017

\section{СВЕАЕНИЯ ОБ АВТОРАХ}

Кудрямов Иван Николаевич (Kudryashov I.N.), науч. сотр. каб. факторов проф. риска ФБУН ЕМНЦ ПОЗРПП Роспотребназзора. E-mail: kudryashov@ymrc.ru. 